\title{
Spatial overlap between foraging seabirds and trawl fisheries: implications for the effectiveness of a marine protected area at Golfo San Jorge, Argentina
}

\author{
PABLO YORIO, FLAVIO QUINTANA, PATRICIA DELL'ARCIPRETE and \\ DIEGO GONZÁLEZ-ZEVALLOS
}

\begin{abstract}
Summary
Assessing human activities and understanding their interaction with seabirds constitute important steps in the development of adequate conservation planning schemes. We evaluated the spatial use of the marine environment by foraging Magellanic Penguins Spheniscus magellanicus and Imperial Cormorants Phalacrocorax atriceps breeding at a newly designated marine park in Golfo San Jorge, Argentina, to assess the potential spatial conflict between these seabirds and commercial hake and shrimp trawl fisheries. GPS loggers were deployed on 45 adults of both species during the 2006 and 2007 breeding seasons. Distribution of hauls made by hake and shrimp trawlers was obtained from the On-board Observer Program of Chubut Province. Penguin foraging range varied between 25.8 and $120.1 \mathrm{~km}$ while cormorant foraging range varied between 1.5 and $68.2 \mathrm{~km}$. Distances travelled to fishing grounds were short for both species $(<4.43 \mathrm{~km})$ and, depending on the season, they spent a significant part of their time at sea within waters used by both fisheries (penguins: 17.9-66.2\%; cormorants: 46.0-89.0\%). In both years, foraging Magellanic Penguins and Imperial Cormorants showed a clear overlap with operating vessels. The observed foraging patterns of penguins and cormorants suggest a high probability of spatial conflict. Moreover, incidental mortality was regularly recorded in both fisheries, at rates that varied between 0.02 and 0.34 individuals per haul depending on species and fishery. Although one of the goals of the new marine park is the protection of Magellanic Penguin and Imperial Cormorant populations, the defined boundaries do not appear to be adequate for their effective protection. Results suggest the need to re-evaluate the spatial design of the park and/or the definition of management actions in waters outside the park to minimise negative effects on penguins and cormorants.
\end{abstract}

\section{Resumen}

La evaluación de las actividades humanas y la comprensión de su interacción con las aves marinas son importantes para la elaboración adecuada de esquemas de planificación para la conservación. Se analizó el uso espacial del ambiente marino por parte de Pingüinos de Magallanes Spheniscus magellanicus y Cormoranes Imperiales Phalacrocorax atriceps reproduciendo en un parque marino recientemente creado en el Golfo San Jorge, Argentina. El objetivo fue evaluar el potencial conflicto espacial entre estas especies y las flotas arrastreras comerciales que operan sobre merluza y langostino. Se colocaron dispositivos GPS en 45 adultos de ambas especies durante las temporadas reproductivas 2006 y 2007. La distribución de lances efectuados por los arrastreros merluceros y langostineros se obtuvo del Programa de Observadores a Bordo de la 
Provincia de Chubut. El rango de forrajeo de los pingüinos varió entre 25,8 y 120, $1 \mathrm{~km}$ mientras que el de los cormoranes varió entre 1,5 y 68,2 km. En ambas especies, las distancias recorridas desde las colonias a las áreas de pesca fueron cortas $(<4,43 \mathrm{~km}) \mathrm{y}$, dependiendo del año, las aves pasaron una parte significativa de su tiempo en el mar dentro de áreas utilizadas por ambas pesquerías (pingüinos: 17,9- 66,2\%; cormoranes: 46,0-89,0 \%). En ambos años, las áreas de alimentación de pingüinos y cormoranes mostraron una clara superposición con las zonas de operación de ambas pesquerías. Los patrones de forrajeo observados para los pingüinos y cormoranes sugieren una alta probabilidad de conflicto espacial con las flotas pesqueras. Es más, se registró mortalidad incidental de aves en ambas pesquerías, con valores que oscilaron entre o,02 y 0,34 individuos por lance dependiendo de la especie y la pesquería. Aunque uno de los objetivos del nuevo parque marino es la protección de las poblaciones del Pingüino de Magallanes y del Cormorán Imperial, los límites definidos del área protegida no parecerían ser adecuados para su protección efectiva. Los resultados sugieren la necesidad de re evaluar el diseño espacial del parque y/o definir acciones de manejo en aguas por fuera del parque para minimizar los efectos negativos sobre pingüinos y cormoranes.

\section{Introduction}

Seabirds are becoming increasingly threatened, and at a faster rate globally than all other groups of birds, as a result of problems related to the marine environment, particularly the interaction with fisheries (Croxall 2008, BirdLife International 2010). Seabird foraging distributions frequently overlap with commercial fisheries, often leading to negative effects such as incidental mortality of seabirds in fishing equipment and competition for common resources (Tasker et al. 2000, Montevecchi 2002, Furness 2003). In this context, mapping human activities and understanding their interaction with seabirds constitute important steps in the development of adequate conservation planning schemes. Growing concern worldwide has resulted in an increasing number of studies exploring the spatial relationship between fisheries and seabirds, confirming or highlighting the potential existence of negative effects (e.g. Phillips et al. 2006, Petersen et al. 2008, Zador et al. 2008, Pichegru et al. 2009, Copello and Quintana 2009).

Magellanic Penguins Spheniscus magellanicus and Imperial Cormorants Phalacrocorax atriceps are two widely distributed seabirds in Patagonia, Argentina (Yorio et al. 1998) and due to their numbers, biomass, and role as high-level predators, they are likely to be important components of these coastal ecosystems. Both species are also important local and regional economic resources. The Magellanic Penguin, internationally recognised as 'Near Threatened' (IUCN 2008), is one of the main ecotourism attractions. Some of its colonies receive over 100,000 visitors per season, generating important revenues at local and regional scales (Yorio et al. 2001a). Imperial Cormorants are the main source of commercially harvested guano in central and southern Patagonia (Punta 1996).

Over $25 \%$ of the total breeding population of both Magellanic penguins and Imperial Cormorants in Patagonia breed at Golfo San Jorge (Frere et al. 2005, Schiavini et al. 2005). This coastal sector, located in central Patagonia, is one of the priority areas for breeding seabirds in Argentina (Fundación Patagonia Natural 1996, Yorio 2000). The area also constitutes the main fishing grounds for one of the most important trawl fisheries in terms of economic return, targeting Argentine Red Shrimp Pleoticus muelleri, and an important fishing ground for the Argentine Hake Merluccius hubbsi (Bezzi et al. 2004, Subsecretaría de Pesca y Acuicultura 2007). Recognition of the environmental value of this area has resulted in the recent decision by the Federal and Provincial Governments to designate this area as a marine protected area (Parque Marino Patagonia Austral), and thus information is urgently needed for the development of a management plan. Our goal was to evaluate the at-sea distribution of breeding Magellanic Penguins and Imperial Cormorants, explore the potential spatial overlap between these seabirds and commercial trawl fisheries, and discuss its implications for the effectiveness of the newly designated marine park to protect their populations. 


\section{Methods}

\section{Study area and species}

The Golfo San Jorge (Fig. I) extends from Cabo Dos Bahías ( $44^{\circ} 55^{\prime} \mathrm{S}, 65^{\circ} 32^{\prime} \mathrm{W}$ ) to Cabo Tres Puntas $\left(47^{\circ} 06^{\prime} \mathrm{S}, 65^{\circ} 52^{\prime} \mathrm{W}\right)$, and includes an area of more than $32,000 \mathrm{~km}^{2}$. Thirteen of the 17 Patagonian breeding seabirds nest on islands of the northern coastal sector of the gulf, including a significant proportion of the Patagonian population of some species (Yorio et al. 1998). Magellanic Penguins breed at 19 colonies of between 30 and 96,000 nests totalling over 240,000 breeding pairs (Schiavini et al. 2005) while Imperial Cormorants breed at 17 colonies of between 20 and 3,000 nests totalling approximately 13,300 breeding pairs (Frere et al. 2005). These estimates of breeding pairs represent about one quarter of the Magellanic Penguin and Imperial Cormorant populations breeding in Patagonia, Argentina (950,000 and 55,000 breeding pairs, respectively). The Magellanic Penguin breeding population in coastal Patagonia is estimated to be over $70 \%$ of the global population (1,300,000 pairs; BirdLife International 2009); unfortunately there are no good estimates of the global population of Imperial Cormorant (Wetlands International 2006). Magellanic Penguins mainly feed on small schooling fish (see review in Schiavini et al. 2005). Their diet at Golfo San Jorge is unknown, but available information from other locations in Chubut province indicates that they mainly feed on Engraulis anchoita, with the contribution of Merluccius hubbsi in some colonies (Gosztonyi 1984, Frere et al. 1996, Scolaro et al. 1999). Imperial Cormorants are a pursuit diving species that feed in relatively coastal waters mostly on fish, although they also include crustaceans, molluscs and polychaetes (see review in Frere et al. 2005). At Golfo San Jorge, main prey recorded during the breeding season consisted of Engraulis anchoita, Merluccius hubbsi, Patagonotothen sp., Helcogrammoides cunninghami and P. muelleri (Punta et al. 2003, Bulgarella et al. 2008, Yorio

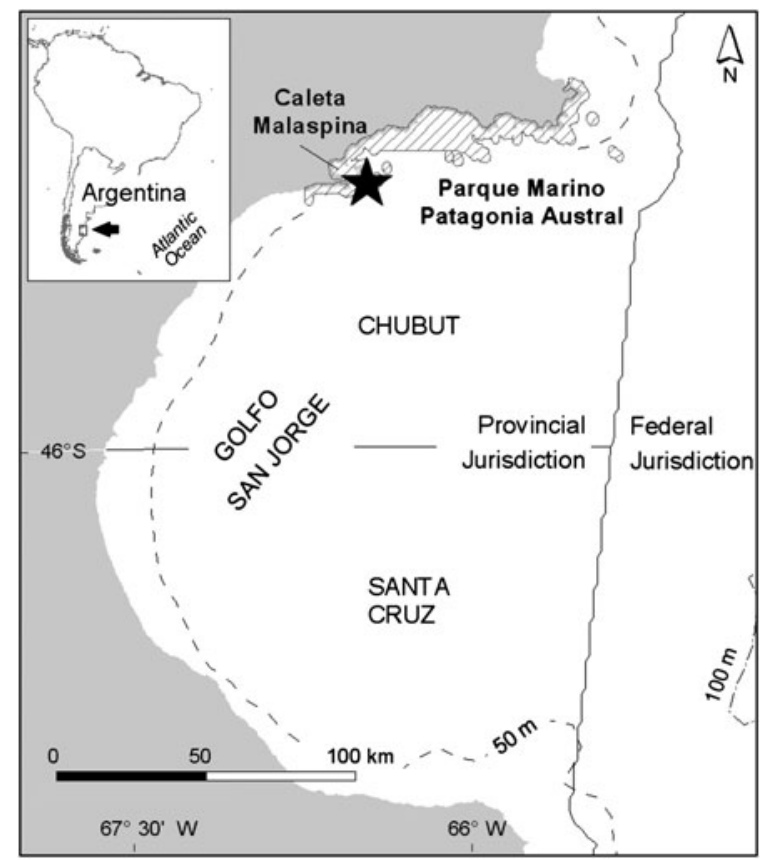

Figure 1. Map of Golfo San Jorge, Argentina, indicating the location of Caleta Malaspina and the Parque Marino Patagonia Austral (see text). 
et al. 2010 Magellanic Penguins and Imperial Cormorants have been recorded taking advantage of discards at different fisheries operating at Golfo San Jorge, but in relatively low frequencies and/or numbers (Yorio and Caille 1999, González-Zevallos and Yorio 2006, González-Zevallos unpubl.data), and thus it is unlikely that their populations benefit much from this supplementary food source.

The recently designated Parque Marino Patagonia Austral (Patagonia Austral Marine Park) (Law 26446, December 2008) includes an area of $750 \mathrm{~km}^{2}$, extending from the high tide mark one nautical mile $(1.85 \mathrm{~km})$ offshore, and is under the joint administration of the Government of the Province of Chubut and the National Parks Administration of Argentina (Figure 1 ). The goals of the Park are to protect representative samples of terrestrial, coastal and marine ecosystems, to ensure the continuity of natural processes and to promote sustainable activities compatible with the conservation of the Park. Several human activities, including commercial fisheries, use the northern sector of Golfo San Jorge. About 70 freezer trawl vessels targeting Argentine Red Shrimp and 20 ice trawlers targeting Argentine Hake operate mostly from September to May. Average annual catches for shrimp and hake fisheries during the study period were estimated at 6,00o and 23,000 tons, respectively (Secretaría de Pesca de la Provincia de Chubut, unpubl. data). In addition, a few small coastal trawlers also fish for Argentine Hake. Fishing grounds have remained the same during the study period (Secretaría de Pesca de la Provincia de Chubut unpubl. data).

\section{Foraging areas and spatial overlap}

The study of foraging seabirds was conducted on birds breeding at Caleta Malaspina $\left(45^{\circ} 10^{\prime} \mathrm{S}\right.$, $66^{\circ} 30^{\prime} \mathrm{W}$ ) (Fig. 1), located at the southern sector of the Parque Marino Patagonia Austral, during the 2006 and 2007 breeding seasons. Breeding numbers of Magellanic Penguins and Imperial Cormorants at the study colonies were estimated at 2,700 and 270 pairs, respectively (Schiavini et al. 2005, Frere et al. 2005). GPS loggers (GPSlog, Earth and Ocean Technologies, Kiel, Germany) were deployed on 45 adult breeders of both sexes (seven female and eight male Magellanic Penguins; 14 female and 16 male Imperial Cormorants) during late November, corresponding to the early chick stage of both species (first 10-15 days after hatching). These loggers recorded time, latitude and longitude once per second, and the horizontal accuracy is considered to be better than $5 \mathrm{~m}$ for $90 \%$ of fixes (GPSlog Manual). The units were streamlined to minimise drag and had maximum dimensions of $95 \times 48 \times 24 \mathrm{~mm}(\mathrm{~L} \times \mathrm{W} \times \mathrm{H})$ and weighed $65 \mathrm{~g}$, representing less than $1.5 \%$ and $2.9 \%$ of Magellanic Penguin and Imperial Cormorant mean body mass, respectively (Yorio et al. 2001b, Svagelj and Quintana 2007). Devices were attached to the feathers of the lower back using waterproof tape (Wilson et al. 1997) to minimise hydrodynamic drag (Bannasch et al. 1994). Every effort was taken to minimize the stress caused to the birds during manipulation. The procedure was completed in less than five minutes and birds quickly returned to their nest. GPS loggers were retrieved when birds came back from the sea and returned to the nest. All birds equipped with devices showed no signs of discomfort due to the attachment of the device and continued breeding normally during the study period. Moreover, previous studies on the two species suggest no alteration of foraging behaviour by birds carrying similar devices (see Wilson and Quintana 2004, Wilson et al. 2004, Quintana et al. 2007, Gómez Laich et al. 2008, Shepard et al. 2009). Localisations of birds at their nests were identified to ground-truth the data and were based on nest position obtained by a commercial GPS unit (GPS III plus, Garmin International). All penguins and half of the cormorants performed just a single foraging trip during the instrumented period. All recorded trips were used to develop maps (see below) while only one trip per bird was used for statistics to avoid pseudoreplication. Means are reported \pm 1 SD.

Spatial analyses were made using ArcView 3.2 (Environmental Systems Research Institute, 1992-1999). Foraging at-sea distributions of seabirds were estimated by fixed kernel method (Worton 1989) and ad hoc calculation of smoothing parameters as implemented in the Animal Movement v2.04 beta extension (Hooge and Eichenlaub 2000). The locations of observed hauls 
made by hake $(n=2,081)$ and shrimp $(n=12,378)$ trawlers between November 15 and March 15 of the 2001-2007 fishing seasons in the fishing area under Chubut jurisdiction south of $44^{\circ} 55^{\prime} \mathrm{S}$ were obtained from the database of the On-board Observer Program of the Chubut Province (Secretaría de Pesca de la Provincia de Chubut unpubl. data). The number of sampled vessels varied among years, representing approximately $14 \%$ and $17 \%$ of the hake and shrimp fishing fleet sizes, respectively. Utilisation areas for the two fishing fleets were estimated using these trawls by fixed kernel method (see above). GPS devices provided the time to the nearest second for each fix, and the amount of time spent by birds at fishing areas was estimated using the accumulated time for all fixes recorded within areas classified as high intensity use $(95 \%$ contours). Sample sizes differ as not all foraging trips were completely recorded or headed to open waters where fishing takes place.

\section{Seabird incidental mortality at trawl vessels}

Information on the number of Magellanic Penguins and Imperial Cormorants killed in nets was gathered on board hake and shrimp trawlers for a total of 179 and 3,367 hauls respectively from 15 November 2004 to 15 March 2005. Information was obtained from the database of the Onboard Observer Program of the Chubut Province. Bird mortality was expressed as average rates per haul. Distance (in $\mathrm{km}$ ) to the nearest shore of each haul with a recorded incidental capture was obtained using ArcView 3.2. Bootstrapping was used to assess confidence intervals around the mean mortality rates (Efron and Tibshirani 1993). For each set of data, 3,00o random resamplings (with replacement) of the original data set were produced, mean mortality rate was calculated, and the results were then sorted to obtain the $95 \%$ confidence interval $(\mathrm{CI})$ of the mean (R Development Core Team 2004).

\section{Results}

\section{Spatial foraging patterns of penguins and cormorants}

In both study years, Magellanic Penguin foraging areas were located south of the colony, mostly following the coastline in 2007 (Figure 2). Imperial Cormorants travelled east and south of their colony, and although they foraged in similar areas during both study seasons, they showed a higher use of the internal waters of Caleta Malaspina during 2007 (Figure 3). Foraging range (maximum distance from the colony) varied between individuals and years, with a maximum of 120.1 and $68.2 \mathrm{~km}$ for Magellanic Penguins (Table 1, Figures 2a and 2b) and Imperial Cormorants (Table 1 , Figure $3 a$ and $3 b$ ), respectively. The duration of Magellanic Penguin foraging trips (defined as the time elapsed between departure and return from the nest/colony) varied between one and two days, while those of Imperial Cormorants were of only a few hours long (Table I).

\section{Seabird spatial overlap with fisheries and incidental mortality}

In both years, foraging Magellanic Penguins and Imperial Cormorants showed a clear overlap with operating vessels of both trawl fisheries (Figure 4 and 5, respectively). Birds remained a significant proportion of their time at sea in waters of high intensity use (95\% kernel contours) by both trawl fisheries (penguins: 17.9-66.2\%; cormorants: 46.0-89.0\%) (Table 2). During foraging excursions, birds reached the areas of high intensity use (95\% kernel contours) soon after leaving their colony (penguins: $<1.30 \mathrm{~h}$; cormorants: $<0.24 \mathrm{~h})($ Table 2 ), and distances travelled to fishing grounds were extremely short for both species $(<4.43 \mathrm{~km})$ (Table 2$)$.

A total of 142 Magellanic Penguins and 54 Imperial Cormorants were killed in nets at both trawl fisheries operating in the Golfo San Jorge during the 2004/2005 fishing season. Mortality rates varied between 0.02 and 0.34 individuals per haul, depending on species and fishery (Table 3 ). The record shows that incidental captures occurred close to shore in both study years (Magellanic 

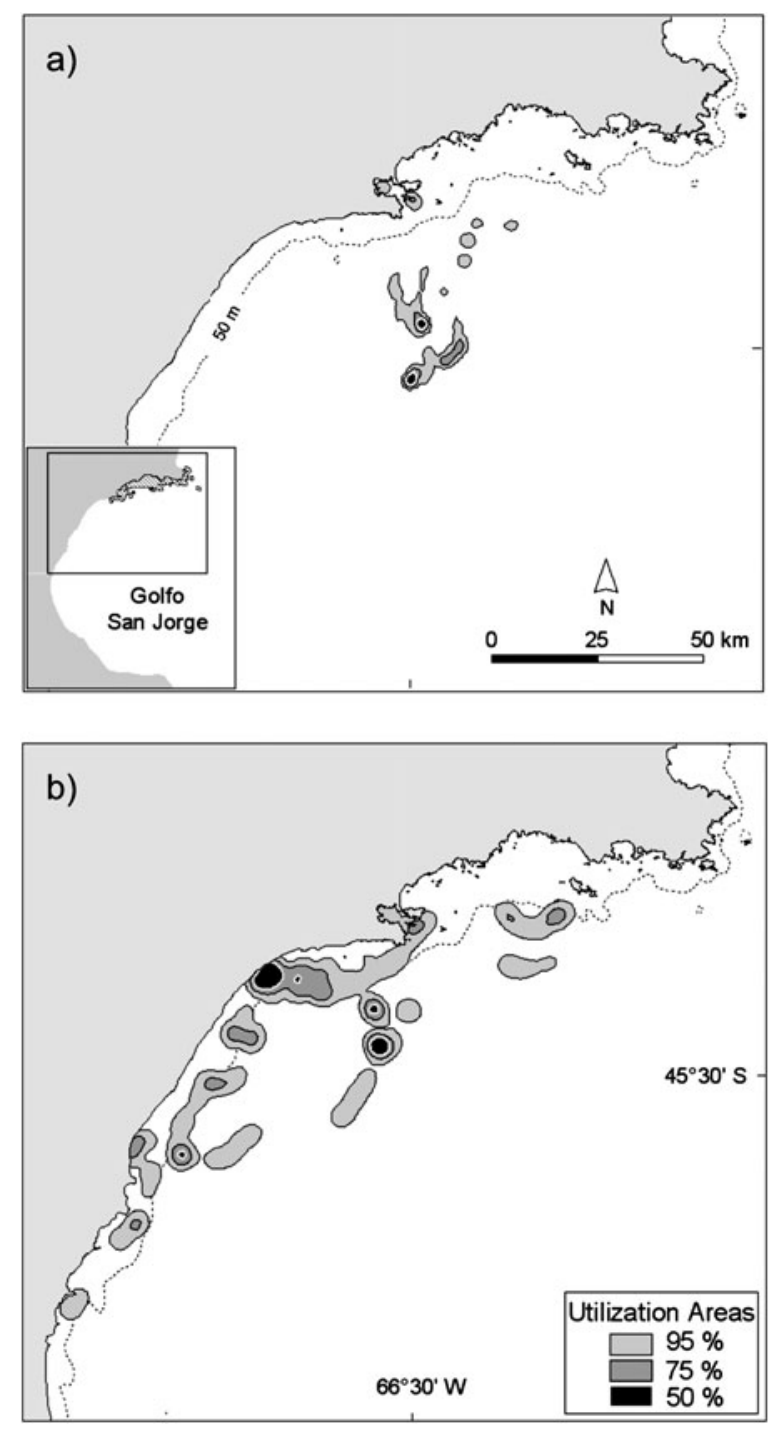

Figure 2. At sea distribution (expressed as locations per unit area) of foraging Magellanic Penguins from Caleta Malaspina, Golfo San Jorge, Argentina, during the chick stage of (a) 2006 $(n=5$ trips $)$ and (b) $2007(n=10$ trips).

Penguins: $6.3 \pm 4.6 \mathrm{~km}$, range $=0.5-18.0, n=142$ birds; Imperial Cormorants: $6.7 \pm 4.9 \mathrm{~km}$, range $=1.1-20.9, n=54$ birds, Figure 6). During the evaluated period, shrimp vessels operated at a mean distance from the coast of $5.0 \pm 4.6 \mathrm{~km}$ (range $=0.1-92.5, n=3,367$ hauls) while hake vessels operated at an estimated distance of $11.5 \pm 5.3 \mathrm{~km}$ (range $=0.2-37.4 ; n=179$ hauls).

\section{Discussion}

Results show that during the chick stage, Magellanic Penguins and Imperial Cormorants forage mostly in coastal waters inside the gulf, travelling up to 120 and $70 \mathrm{~km}$ from the colony, 

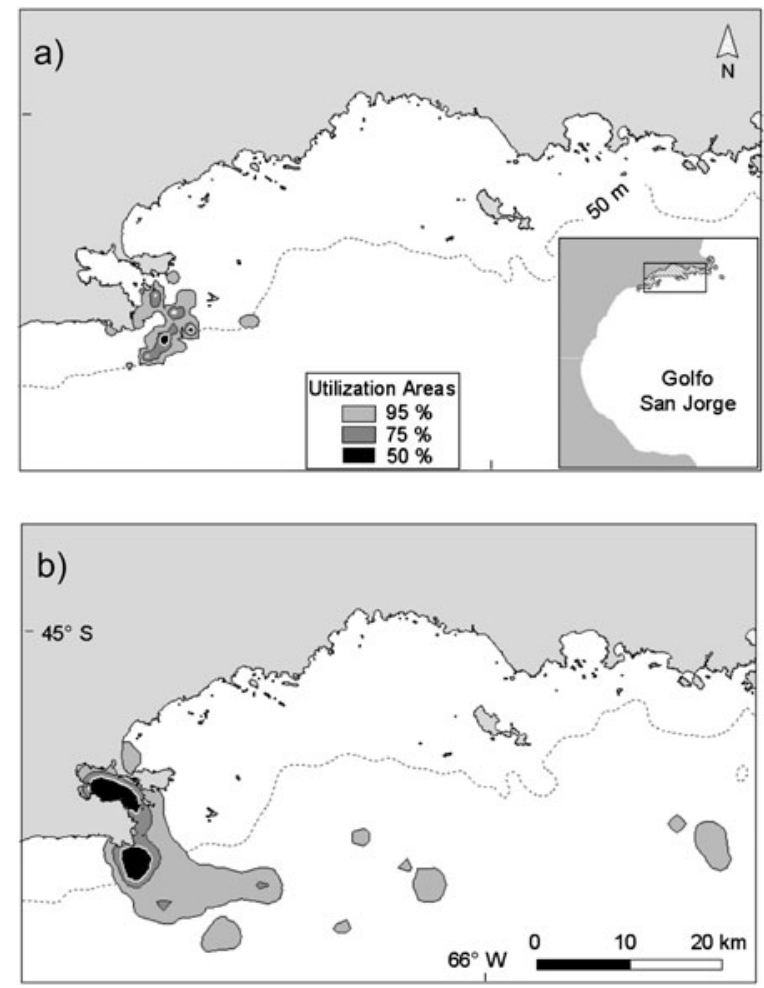

Figure 3. At sea distribution (expressed as locations per unit area) of foraging Imperial Cormorants breeding at Caleta Malaspina, Golfo San Jorge, Argentina, during the chick stage of (a) 2006 ( $n=22$ trips) and (b) 2007 ( $n=25$ trips).

respectively. Magellanic Penguins and Imperial Cormorants were recorded feeding in similar coastal sectors, although the latter showed larger foraging ranges. Distances travelled by Magellanic Penguins in our study were similar to those recorded during the chick stage at other locations in Patagonia (Wilson et al. 2005, Boersma et al. 2007, Boersma and Rebstock 2009). It should be noted, however, that Magellanic Penguin foraging patterns obtained in this study should be interpreted with caution given that they were derived from a relatively low sample size. Imperial Cormorants feeding areas were also located mostly close to shore. Results of their foraging patterns agree with previous evaluations in the same study area, where Imperial Cormorants instrumented with radio-transmitters travelled further than $8 \mathrm{~km}$ from the colony (Sapoznikow and Quintana 2003) and individuals instrumented with time-depth recorders foraged up to depths of $70 \mathrm{~m}$ (at least $10 \mathrm{~km}$ from the colony) (Quintana et al. 2007). Although the information obtained in the present study is restricted to the early chick stage, it provides valuable insights into potential conflicts between foraging seabirds and fisheries. However, further studies are needed to assess spatial needs of foraging birds at other stages of the breeding cycle, as studies on Magellanic Penguins and other seabirds have shown that spatial requirements are larger during the incubation stage (e.g. Boersma et al. 2002, Huin 2002, Boersma and Rebstock 2009).

Both Magellanic Penguins and Imperial Cormorants foraged within the waters of the gulf, overlapping with hake and shrimp fisheries during their foraging trips. Birds breeding at Caleta Malaspina arrived at fishing grounds shortly after leaving their colony and, depending on the 
Table 1. Foraging patterns of Magellanic Penguins and Imperial Cormorants breeding at Caleta Malaspina, Golfo San Jorge, Argentina, during the 2006 and 2007 breeding seasons (mean \pm SD with range in parentheses).

\begin{tabular}{lllll}
\hline Species & Year & $\begin{array}{l}\text { Maximum distance } \\
\text { from the colony }(\mathrm{km})\end{array}$ & $\begin{array}{l}\text { Maximum distance } \\
\text { to the nearest } \\
\text { coastline }(\mathrm{km})\end{array}$ & $\begin{array}{l}\text { Foraging } \\
\text { trip duration } \\
(\mathrm{h})\end{array}$ \\
\hline Magellanic Penguin & $2006(n=5)$ & $38.2 \pm 9.0(25.8-48.2)$ & $30.2 \pm 7.6(22.7-40.0)$ & $29.5 \pm 7^{(1)}$ \\
& $2007(n=10)$ & $57.5 \pm 29.1(24.7-120.1)$ & $18.9 \pm 10.9(4.7-37.7)$ & $37.7 \pm 16.4$ \\
Imperial Cormorant & $2006(n=13)$ & $7.8 \pm 4.9(1.5-17.9)$ & $6.2 \pm 4.6(1.6-17.3)$ & $4.4 \pm 2.2$ \\
& $2007(n=17)$ & $14.7 \pm 17.0(2.3-68.2)$ & $8.9 \pm 10.3(0.9-29.2)$ & $4.4 \pm 1.5$ \\
\hline
\end{tabular}

${ }^{(1)} n=3 ;{ }^{(2)} n=5$

season, spent a significant part of their time at sea within the waters used by both fishing fleets. The observed foraging ranges and time spent by both species at hake and shrimp fishing grounds suggest a high probability of spatial conflict. Potential spatial conflicts with fishing operations may not be restricted to seabirds breeding at Caleta Malaspina. Magellanic Penguins and Imperial
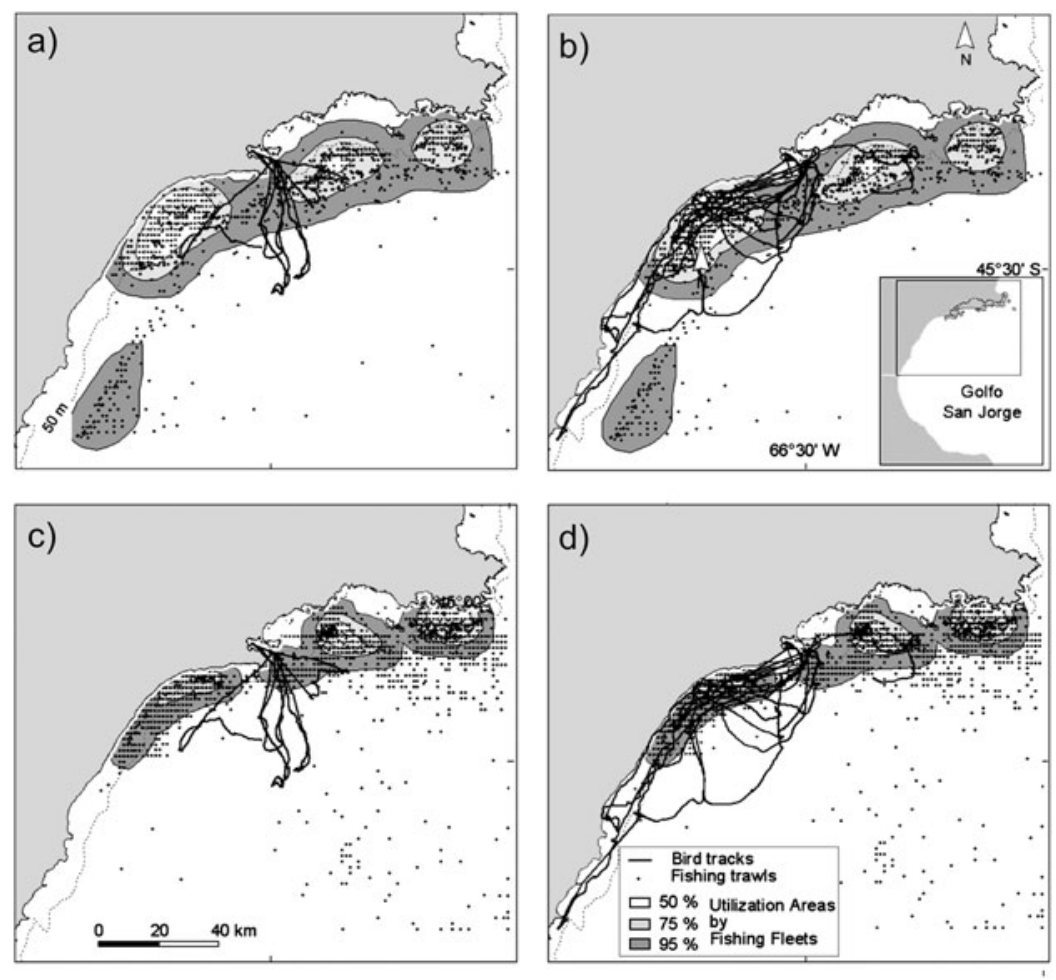

Figure 4. Tracks of foraging Magellanic Penguins instrumented at Caleta Malaspina during the chick stage of 2006 ( $a$ and c) and 2007 (b and d), and spatial distribution of hauls made by hake trawlers ( $a$ and $b$ ) and shrimp trawlers ( $c$ and d) between November 15 and March 15 of the 2001-2007 fishing seasons at Golfo San Jorge, Argentina. Grey areas indicate the areas of high intensity use by hake and shrimp trawl fisheries (95, 75 and 50\% kernel contours). 

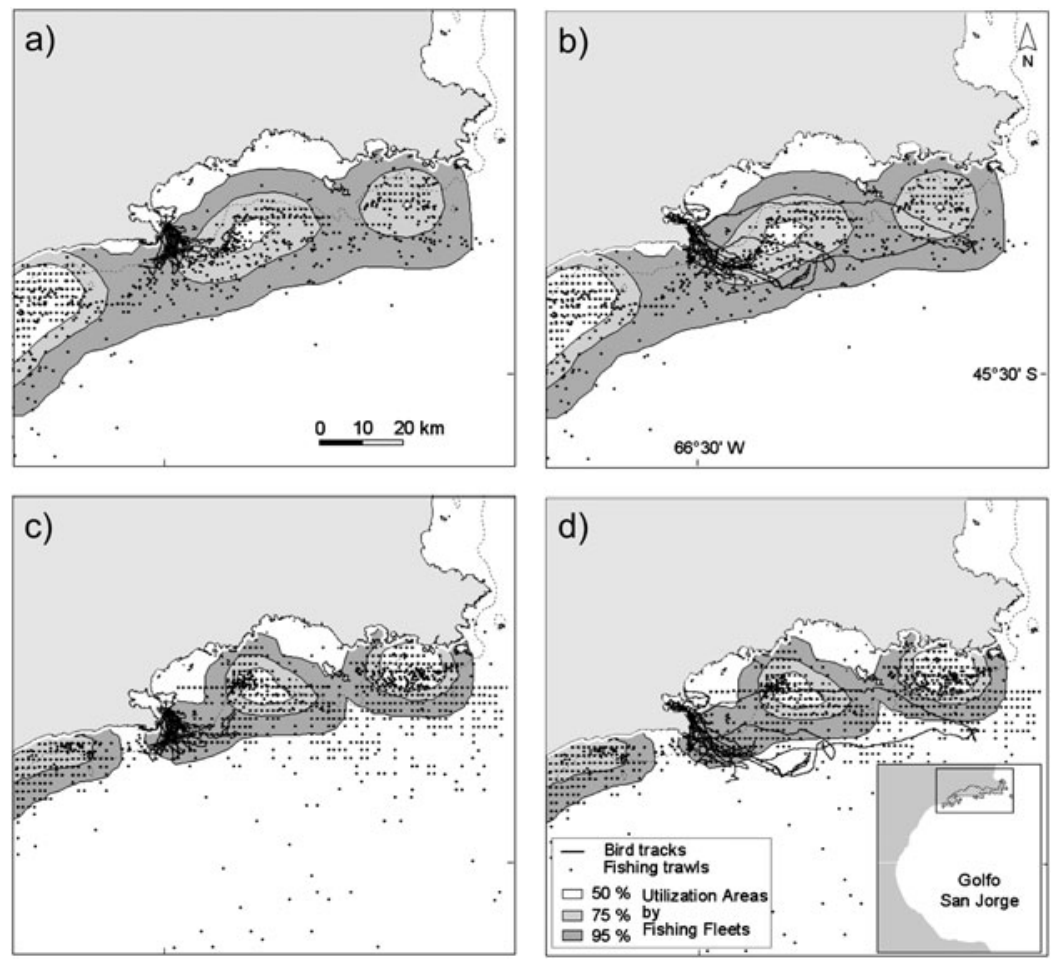

Figure 5. Tracks of foraging Imperial Cormorants instrumented at Caleta Malaspina during the chick stage of 2006 (a and c) and 2007 (b and d) and spatial distribution of hauls made by hake trawlers ( $a$ and b) and shrimp trawlers ( $c$ and d) between November 15 and March 15 of the 2001-2007 fishing seasons at Golfo San Jorge, Argentina. Grey areas indicate the areas of high intensity use by hake and shrimp trawl fisheries $(95,75$ and 50\% kernel contours).

Cormorants nest in a total of 19 and 17 colonies, respectively, along the $100 \mathrm{~km}$ coastal sector of northern Golfo San Jorge (see Study Area). All these colonies are located within less than $20 \mathrm{~km}$ of the areas of high intensity use by hake and shrimp trawl vessels, with more than $70 \%$ of them at even less than $5 \mathrm{~km}$ (Figure 7). Even recognising the potential variability in foraging range among colonies, a simple extrapolation of the maximum foraging ranges obtained for penguins and cormorants from Caleta Malaspina to neighbouring colonies in northern Golfo San Jorge indicates that at all these locations feeding seabirds and trawl vessels can show a significant spatial overlap (Figure 7).

Hake and shrimp trawl fisheries produce significant amounts of fishery discards, which are thrown overboard (Cordo 2005, González-Zevallos and Yorio 2006). These attract large number of seabirds, including Magellanic Penguins and Imperial Cormorants (González-Zevallos and Yorio 2006). Both species take advantage of discards using the pursuit diving method, obtaining discards directly from, or falling off, the net during haul-back, thus increasing their chances of becoming entangled (González-Zevallos and Yorio 2006). This attraction to fishing vessels to make use of waste is very likely an important factor influencing the mortality from drowning in nets observed in this and previous studies in Golf San Jorge (Gandini et al. 1999, GonzálezZevallos and Yorio 2006). Unfortunately, the effects of the estimated incidental mortality on the population dynamics of penguins and cormorants breeding at Golfo San Jorge is still unknown, but mortality of adult individuals should not be underestimated given the life-history traits of 
Table 2. Average time spent in fishing areas relative to the duration of the trip (\%), average travel time (h) and distance to fishing grounds $(\mathrm{km})$ for foraging Magellanic Penguins and Imperial Cormorants breeding at Caleta Malaspina, Golfo San Jorge, Argentina. Fishing areas are those represented by the $95 \%$ probability kernel contour (see Figures 4 and 5).

\begin{tabular}{|c|c|c|c|c|c|c|c|}
\hline \multirow[t]{2}{*}{ Species } & \multirow[t]{2}{*}{ Year } & \multicolumn{2}{|c|}{$\begin{array}{l}\text { Time at fishing } \\
\text { area relative to } \\
\text { total trip time }(\%)\end{array}$} & \multicolumn{2}{|c|}{$\begin{array}{l}\text { Travel time to } \\
\text { fishing area }(\mathrm{h})\end{array}$} & \multicolumn{2}{|c|}{$\begin{array}{l}\text { Distance to fishing } \\
\text { area }(\mathrm{km})\end{array}$} \\
\hline & & $\begin{array}{l}\text { Hake } \\
\text { fishery }\end{array}$ & $\begin{array}{l}\text { Shrimp } \\
\text { fishery }\end{array}$ & $\begin{array}{l}\text { Hake } \\
\text { fishery }\end{array}$ & $\begin{array}{l}\text { Shrimp } \\
\text { fishery }\end{array}$ & $\begin{array}{l}\text { Hake } \\
\text { fishery }\end{array}$ & $\begin{array}{l}\text { Shrimp } \\
\text { fishery }\end{array}$ \\
\hline \multirow[t]{2}{*}{ Magellanic Penguin } & $2006(n=3)$ & 31.8 & 17.9 & 0.94 & 0.41 & $3 \cdot 35$ & 1.75 \\
\hline & $2007(n=5)$ & 66.2 & 54.1 & 1.30 & 0.82 & $4 \cdot 43$ & 2.87 \\
\hline \multirow[t]{2}{*}{ Imperial Cormorant } & $2006(n=13)$ & 89.0 & 88.6 & $0.16^{(1)}$ & 0.00 & $1.02^{(1)}$ & 0.00 \\
\hline & $2007(n=17)$ & 52.5 & 46.0 & $0.24^{(2)}$ & $0.08^{(2)}$ & $3.00^{(2)}$ & $0.91^{(2)}$ \\
\hline
\end{tabular}

(1) $n=12 ;{ }^{(2)} n=9$

seabirds (Furness and Monaghan 1987, Sæther and Bakke 2000). Similarly, information is insufficient to evaluate the effects of trawl fisheries on penguin and cormorant trophic resources through extraction and habitat disturbance.

Spatial foraging patterns of Magellanic Penguins and Imperial Cormorants suggest that fisheries operations could potentially affect their populations breeding within the gulf and, in addition, trigger the occurrence of negative interactions with wildlife based tourism and guano harvesting. Although Magellanic Penguin and Imperial Cormorant populations are among the targets of the recently designated marine park, the defined boundaries do not appear to be adequate for their effective protection. The obtained information shows that both Magellanic Penguins and Imperial Cormorants forage mostly beyond the limits of the park, where they overlap with trawl fisheries and may be killed in fishing gear. Marine protected areas are in general ineffective for the protection of highly mobile species such as seabirds (Boersma and Parrish 1999, Hyrenbach et al. 2000, Yorio 2000), but some degree of protection of seabird breeding populations might be achieved by including relatively small extensions of adjacent sea to colony locations because these birds are central place foragers. However, given the scale at which penguins and cormorants forage it is unlikely that the needed protection will be afforded by the marine park, and thus the spatial design of the park needs to be re-evaluated and/or offboundary actions and specific governance arrangements will have to be developed to address the complexities of the marine system under consideration (Yorio 2009). It is expected that the information presented in this study will help raise awareness among managers and stakeholders of the potential conflicts between fisheries and breeding seabirds and contribute to both the development of the management plan for the recently designated Marine Park and a conservation strategy for the Golfo San Jorge's marine wildlife and environments.

Table 3. Mortality rate of Magellanic Penguins and Imperial Cormorants at the hake and shrimp trawl fisheries operating in Golfo San Jorge, Argentina, during the 2004/2005 fishing season.

\begin{tabular}{|c|c|c|c|c|}
\hline \multirow[t]{2}{*}{ Fishery } & \multicolumn{2}{|c|}{ Magellanic Penguin } & \multicolumn{2}{|c|}{ Imperial Cormorant } \\
\hline & $\begin{array}{l}\mathrm{N}^{\circ} \\
\text { killed }\end{array}$ & $\begin{array}{l}\text { Rate (ind./haul) } \\
(95 \% \mathrm{CI})\end{array}$ & $\begin{array}{l}\mathrm{N}^{\circ} \\
\text { killed }\end{array}$ & $\begin{array}{l}\text { Rate (ind./haul) } \\
\text { (95\% CI) }\end{array}$ \\
\hline Hake fishery $(n=179)$ & 37 & $0.34(0.23-0.46)$ & 5 & $0.04(0.01-0.06)$ \\
\hline Shrimp fishery $(n=3367)$ & 105 & $0.04(0.03-0.05)$ & 49 & $0.02(0.01-0.04)$ \\
\hline
\end{tabular}



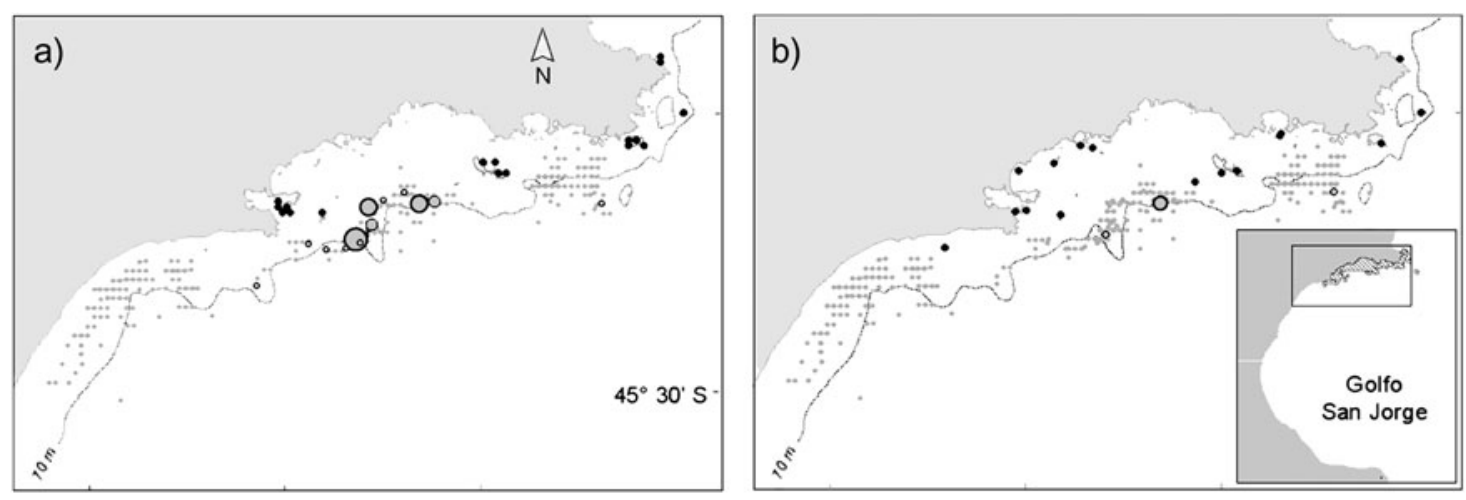

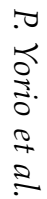
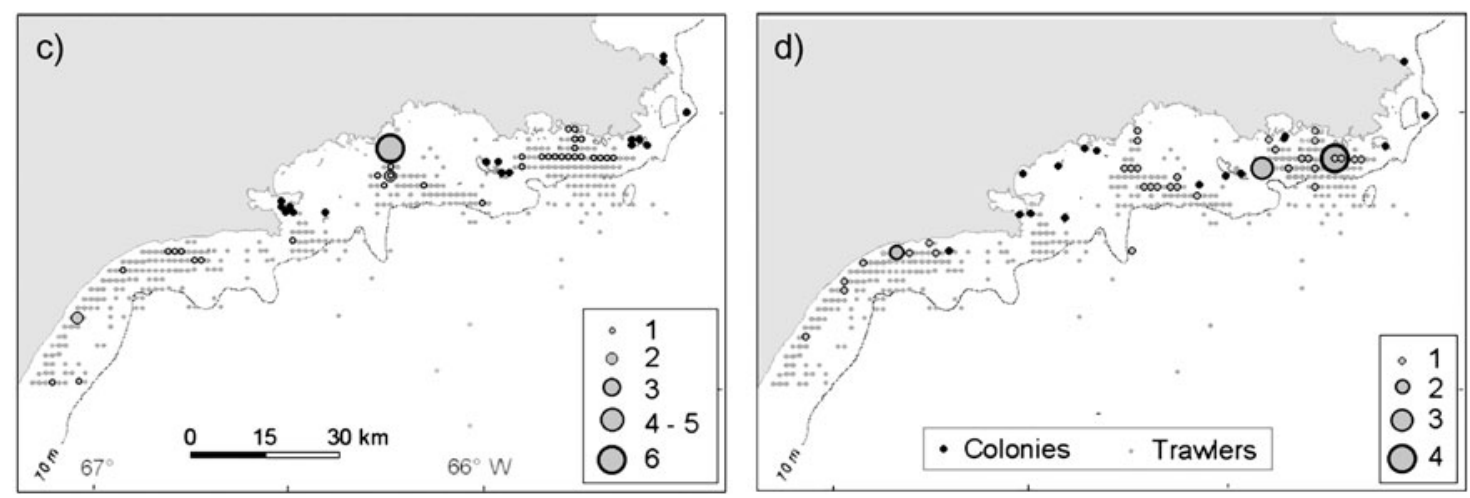

Figure 6. Spatial distribution of Magellanic Penguin and Imperial Cormorant incidental mortality in hake (a and b) and shrimp (c and d) trawl fisheries operating at Golfo San Jorge between 2004 and 2005. Grey circles indicate number of individuals incidentally captured per trawl; black circles indicate location of colonies. Source: On-board Observer Program of Chubut Province. 

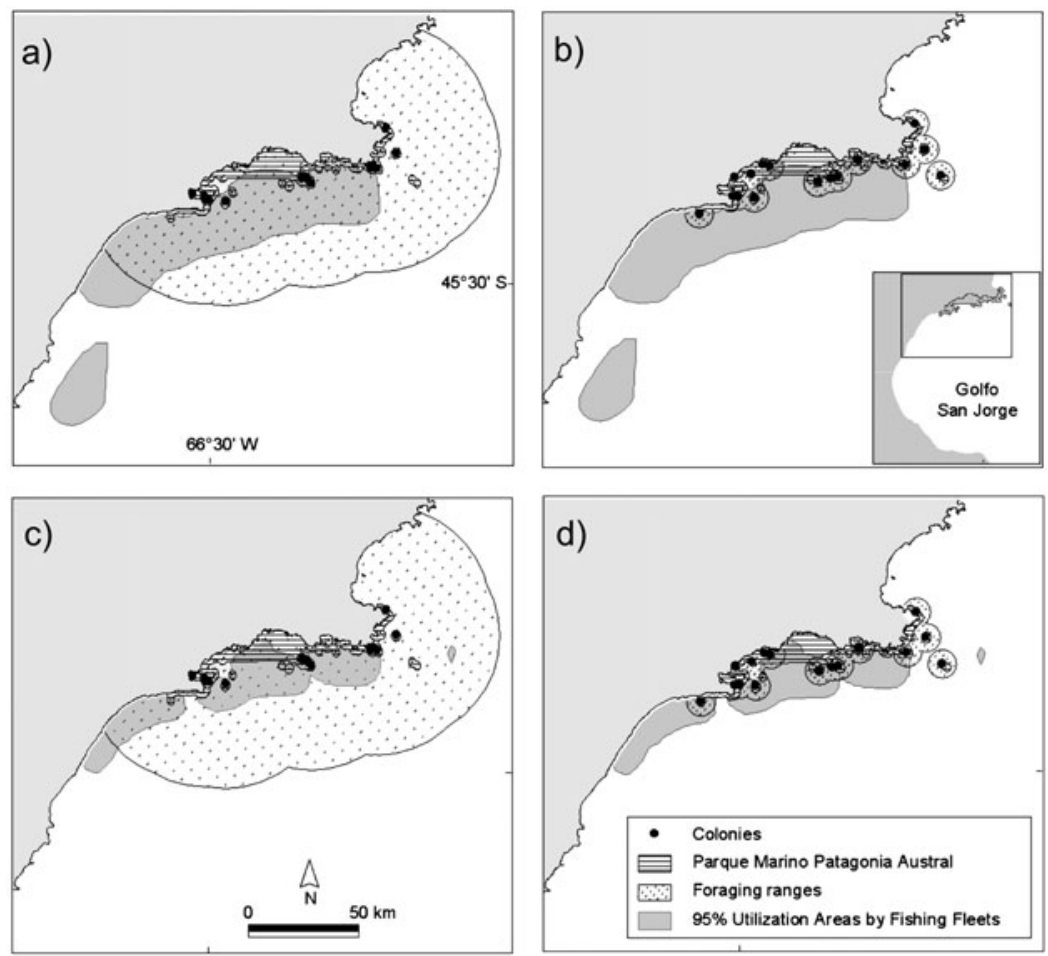

Figure 7. Estimated overlap between hake and shrimp trawl fisheries and foraging Magellanic Penguins and Imperial Cormorants breeding in colonies in the north of Golfo San Jorge, Argentina. The hatched area shows the potential foraging area of Magellanic Penguins (a and c) and Imperial Cormorants ( $b$ and d) during the early chick stage, estimated using the maximum foraging distance obtained for the two species at the Caleta Malaspina colonies (see text). Grey areas indicate the areas of high intensity use by hake (a and b) and shrimp (c and d) trawl fisheries (95\% Kernel contours); black circles indicate location of colonies.

\section{Acknowledgements}

Research was funded by grants from the Wildlife Conservation Society and Proyecto ARG/ PNUD ARG 02/o18 Conservación de la Diversidad Biológica y Prevención de la Contaminación Marina en Patagonia. We thank R. Wilson, E. Shepard, A. Gómez-Laich, and R. Vera for field assistance and J. Lancellotti for help in data analysis. We also thank Centro Nacional Patagónico (CONICET) for institutional support, Soriano S.A. and the On-board Observer Program of the Chubut Province for logistical support and access to data, and the captains and crews of the hake shrimp trawlers for their help and advice.

\section{References}

Bannasch, R., Wilson, R. P. and Culik, B. (1994) Hydrodynamic aspects of design and attachment of a back-mounted device in penguins. J. Exp. Biol. 194: 83-96.
Bezzi, S. I., Renzi, M., Hirsuta, G., Santos, B., Tringali, L. S., Ehrlich, M. D., Sánchez, F., García de la Rosa, S. B., Simonazzi, M. and Villarino, M. F. (2004) Caracterización 
biológica y pesquera de la merluza (Merluccius hubbsi). Pp. 157-205 in R. Sánchez and S. Bezzi, eds. El Mar Argentino y sus recursos pesqueros. Tomo 4. Los peces marinos de interés pesquero. Caracterización biológica y evaluación del estado de explotación. Mar del Plata, Argentina: Publicaciones Especiales INIDEP.

BirdLife International (2009) Species factsheet: Spheniscus magellanicus. Downloaded from http://www.birdlife.org on 7/1/2010

BirdLife International (2010) Global Seabird Programme. http://www.birdlife.org

Boersma, P. D. and Parrish, J. K. (1999) Limiting abuse: marine protected areas, a limited solution. Ecol. Econ. 31: 287-304.

Boersma, P. D. and Rebstock, G. A. (2009) Foraging distance affects reproductive success in Magellanic penguins. Mar. Ecol. Prog. Ser. 375: 263-275.

Boersma, P. D., Rebstock, G. A., Stokes, D. L. and Majluf, P. (2007) Oceans apart: conservation models for two temperate penguin species shaped by the marine environment. Mar. Ecol. Prog. Ser. 335: 217-225.

Boersma, P. D., Stokes, D. L. and Strange, I. J. (2002) Applying ecology to conservation: tracking breeding penguins at New Island South reserve, Falkland Islands Aquat. Conserv. 12: 63-74.

Bulgarella, M., Cella Pizarro, L., Quintana, F., Sapoznikow, A., Gosztonyi, A. and Kuba, L. (2008) Diet of Imperial Cormorants (Phalacrocorax atriceps) and Rock Shags (P. magellanicus) breeding sympatrically in Patagonia, Argentina. Ornitol. Neotrop. 19: $553-563$.

Copello, S. and Quintana, F. (2009) Spatiotemporal overlap between the at-sea distribution of Southern Giant Petrels and fisheries at the Patagonian Shelf. Polar Biol. 32: 1211-1220.

Cordo, H. D. (2005) Evaluación del estado del efectivo sur de $41^{\circ} \mathrm{S}$ de la Merluza (Merluccius hubbsi) y estimación de la captura biológicamente aceptable orrespondiente al año 2005. Informe Técnico Interno INIDEP 37: 1-19.

Croxall, J. P. (2008) The role of science and advocacy in the conservation of Southern Ocean albatrosses at sea. Bird Conserv. Int. 18 (Suppl. 1): S13-S29.
Efron, B. and Tibshirani, R. J. (1993) An introduction to the bootstrap. London, UK: Chapman \& Hall.

Frere, E., Gandini, P. A. and Lichtschein, V. (1996) Variación latitudinal en la dieta del Pingüino de Magallanes (Spheniscus magellanicus) en la costa Patagónica, Argentina. Ornitol. Neotrop. 7: 35-41.

Frere, E., Quintana, F. and Gandini, P. (2005) Cormoranes de la costa patagónica: estado poblacional, ecología y conservación. Hornero 20: 35-52.

Fundación Patagonia Natural (1996) Plan de manejo integrado de la Zona Costera Patagónica: diagnosis y recomendaciones para su elaboración. Puerto Madryn, Argentina: Fundación Patagonia Natural and Wildlife Conservation Society.

Furness, R. W. (2003) Impacts of fisheries on seabird communities. Sci. Mar. 67 (Suppl. 2): $33-45$.

Furness, R. W. and Monaghan, P. (1987) Seabird ecology. Glasgow, UK: Blackie.

Gandini, P., Frere, E., Pettovello, A. D. and Cedrola, P. V. (1999) Interaction between Magellanic penguins and shrimp fisheries in Patagonia, Argentina. Condor 101: 783-789.

Gómez Laich, A., Wilson, R., Quintana, F. and Shepard, E. (2008) Identification of Imperial Cormorant, Phalacrocorax atriceps, behaviour using accelerometers. Endang. Species Res. DOI 10.3354/esrooo91.

González-Zevallos, D. and Yorio, P. (2006) Seabird use of waste and incidental captures at the Argentine hake trawl fishery in Golfo San Jorge, Argentina. Mar. Ecol. Prog. Ser. 316: 175-183.

Gosztonyi, A. E. (1984) La alimentación del pingüino Magallánico (Spheniscus magellanicus) en las adyacencias de Punta Tombo, Chubut, Argentina. Contribución Centro Nacional Patagónico 95: 1-19.

Hooge, P. N. and Eichenlaub, B. (2000) Animal movement extension to Arcview. Ver. 2.04. Anchorage, USA: Alaska Science Center-Biological Science Office, U.S. Geological Survey. http://www.absc.usgs.gov/ $\mathrm{glba} / \mathrm{gistools} /$ index.htm

Huin, N. (2002) Foraging distribution of the black-browed albatross, Thalassarche melanophris, breeding in the Falkland Islands. Aquat. Conserv. 12: 89-99. 
Hyrenbach, K. D., Forney, K. A. and Dayton, P. K. (2000) Marine protected areas and ocean basin management. Aquat. Conserv. 10: $437-458$.

IUCN (2008) 2008 IUCN Red List of threatened species. <www.iucnredlist.org > Downloaded on 03 May 2009.

Montevecchi, W. A. (2002) Interactions between fisheries and seabirds. Pp. 527-555 in E. A. Schreiber and J. Burger, eds. Biology of marine birds. Washington DC: CRC Press.

Petersen, S. L., Phillips, R. A., Ryan, P. G. and Underhill, L. (2008) Albatross overlap with fisheries in the Benguela Upwelling System: implications for conservation and management. Endang. Species Res. 5: 117-127.

Phillips, R. A., Silk, J. R. D., Croxall, J. P. and Afanasyev, V. (2006) Year-round distribution of white-chinned petrels from South Georgia: relationships with oceanography and fisheries. Biol. Conserv. 129: 336-347.

Pichegru, L., Ryan, P. G., Le Bohec, C., van der Lingen, C. D., Navarro, R., Petersen, S. Lewis, S., van der Westhuizen, J. and Grémillet, D. (2009) Overlap between vulnerable top predators and fisheries in the Benguela upwelling system: implications for marine protected areas. Mar. Ecol. Prog. Ser. 391: 199-208.

Punta, G. E. (1996) Estado de situación del recurso guanero en la República Argentina. Informes Técnicos del Plan de Manejo Integrado de la Zona Costera Patagónica, Fundación Patagonia Natural 6: 1-19.

Punta, G., Yorio, P. and Herrera, G. (2003) Temporal patterns in the diet and food partitioning in Imperial Cormorants (Phalacrocorax atriceps) and Rock Shags ( $P$. magellanicus) breeding at Bahía Bustamante, Argentina. Wilson Bull. 115: 308316.

Quintana, F., Wilson, R. and Yorio, P. (2007) Dive depth and plumage air in wettable birds: the extraordinary case of the imperial cormorant. Mar. Ecol. Prog. Ser. 334: 299-310.

R Development Core Team (2004) R: A language and environment for statistical computing. Vienna, Austria: R Foundation for Statistical Computing.
Sæther, B.-E.. and Bakke, Ø. (200o) Avian life history variation and contribution of demographic traits to the population growth rate. Ecology 81: 642-653.

Sapoznikow, A. and Quintana, F. (2003) Foraging behavior and feeding locations of Imperial Cormorants and Rock Shags breeding in sympatry in Patagonia, Argentina. Waterbirds 26: 184-191.

Schiavini, A., Yorio, P., Gandini, P., Raya Rey, A. and Boersma, D. (2005) Los pingüinos de las costas argentinas: estado poblacional y conservación. Hornero 20: 5-23.

Scolaro, J. A., Wilson, R. P., Laurenti, S., Kierspel, M. A., Gallelli, H. and Upton, J. A. (1999) Feeding preferences of the Magellanic Penguin Spheniscus magellanicus over its breeding range in Argentina. Waterbirds 22:104-110.

Shepard, E. L. C., Wilson, R. P., Quintana, F., Gómez Laich, A. and Forman, D. W. (2009) Pushed for time or saving on fuel: fine-scale energy budgets shed light on currencies in a diving bird. P. Roy. Soc. Lond.

Subsecretaría de Pesca y Acuicultura (2007) Pesquerías de calamar y langostino: situación actual. Buenos Aires: Secretaría de Agricultura, Ganadería, Pesca y Alimentos de la República Argentina.

Svagelj, S. W. and Quintana, F. (2007) Sexual size dimorphism and determination by morphometric measurements in breeding Imperial Shags (Phalacrocorax atriceps). Waterbirds 30: 97-102.

Tasker, M., Camphuysen, C. J., Cooper, J., Garthe, S., Montevecchi, W. A. and Blaver, S. J. M. (2000) The impacts of fishing on marine birds. ICES J. Mar. Sci. 57: 531-547.

Wetlands International (2006) Waterbird population estimates - fourth edition. Wageningen, The Netherlands: Wetlands International.

Wilson, R. and Quintana, F. (2004) Surface pauses in relation to dive duration in Imperial Cormorants; how much for a breather? J. Exp. Biol. 207: 1789-1796.

Wilson, R. P., Kreye, J., Lucke, K. and Urquardt, H. (2004) Antennae on transmitters on free-living marine animals: Balancing energy budgets on the high wire. J. Exp. Biol. 207: 2649-2662. 
Wilson, R. P., Pütz, K., Peters, G., Culik, B., Scolaro, A. J., Charrasin, J. B. and RoupertCoudert, Y. (1997) Long-term attachment of transmitting and recording devices to penguins and other seabirds. Wildl. Soc. Bull. 25: 101-106.

Wilson, R., Scolaro, J. A., Grémillet, D., Kierspel, M., Laurenti, S., Upton, J., Gallelli, H., Quintana, F., Frere, E., Müller, G., thor Straten, M. and Zimmer, I. (2005) How do Magellanic penguins cope with variability in their access to prey? Ecol. Monogr. 75: 379-401.

Worton, B. J. (1989) Kernel methods for estimating the utilization distribution in home-range studies. Ecology 70: 164-168.

Yorio, P. (2000) Breeding seabirds of Argentina: conservation tools for a more integrated and regional approach. Emu ıоo: $367-375$.

Yorio, P. (2009) Marine protected areas, spatial scales and governance: implications for the conservation of breeding seabirds. Conserv. Lett. 2: 171-178.

Yorio, P. and Caille, G. (1999) Seabird interactions with coastal fisheries in northern Patagonia: use of discards and incidental captures in nets. Waterbirds 22: 207216.
Yorio, P., Copello, S., Kuba, L., Gosztonyi, A. and Quintana, F. (2010) Diet of Imperial Cormorants, Phalacrocorax atriceps, breeding at central Patagonia, Argentina. Waterbirds.

Yorio, P., Frere, E., Gandini, P. and Harris, G., eds. (1998) Atlas de la distribución reproductiva de aves marinas en el litoral Patagónico Argentino. Plan de Manejo Integrado de la Zona Costera Patagónica. Buenos Aires, Argentina: Instituto Salesiano de Artes Gráficas, Fundación Patagonia Natural y Wildlife Conservation Society.

Yorio, P., Frere, E., Gandini, P. and Schiavini, A. (2001a) Tourism and recreation at seabird breeding sites in Patagonia, Argentina: current concerns and future prospects. Bird Conserv. Int. 11: 231-245.

Yorio, P., García Borboroglu, P., Potti, J. and Moreno, J. (2001b) Breeding biology of Magellanic penguins Spheniscus magellanicus at Golfo San Jorge, Patagonia, Argentina. Mar. Orn. 29: 75-79.

Zador, S. G., Parrish, J. K., Punt, A. E., Burke, J. L. and Fitzgerald, S. M. (2008) Determining spatial and temporal overlap of an endangered seabird with a large commercial trawl fishery. Endang. Species Res. 5: 103-115.

\section{PABLO YORIO*, FLAVIO QUINTANA}

Centro Nacional Patagónico (CONICET), Bv. Brown 2915, (9120) Puerto Madryn, Chubut, Argentina and Wildlife Conservation Society, Virrey del Pino 2632, P 19, Dpto. B, Ciudad de Buenos Aires, Argentina.

\section{PATRICIA DELL'ARCIPRETE, DIEGO GONZÁLEZ-ZEVALLOS}

Centro Nacional Patagónico (CONICET), Bv. Brown 2915, (9120) Puerto Madryn, Chubut, Argentina.

${ }^{*}$ Author for correspondence; e-mail: yorio@cenpat.edu.ar

Received 20 August 2009; revision accepted 13 March 2010; Published online 26 April 2010 